\title{
Geographic pattern of genetic diversity in natural populations of Rosewood (Aniba rosaeodora), in the Central Amazonia
}

\author{
Ronaldo Pereira SANTOS ${ }^{1}$, Paula Cristina da Silva ÂNGELO², Paulo de Tarso Barbosa SAMPAIO ${ }^{3}$, Regina \\ Caetano QUISEN ${ }^{4}$, Ângela Maria Conte LEITE5 ${ }^{5}$ Cristiane Lopes de OLIVEIRA ${ }^{6}$
}

\begin{abstract}
Rosewood (Aniba rosaeodora Ducke, Lauraceae) is an Amazonian evergreen tree and a source of the purest linalool, the main component of its essential oil, which is very valuable in the international perfumery market. After decades of over-exploitation it is currently considered as threatened. We evaluated the genetic diversity and its distribution in four populations in Central Amazonia. Thirty-five reliable RAPD markers were generated, of which 32 were polymorphic (91.4\%). Variation was higher within the populations $(76.5 \%$; $<<0.0001)$ and geographic distribution contributed to population differentiation $(23.4 \%$; $\mathrm{p}$ $<0.0001)$. The Amazon River had a small influence on gene flow (3.3\%; $<<0.0001)$, but we identified evidence of gene flow across the river. There were significant differences in marker frequencies $(\mathrm{p}<0.05)$, in agreement with the low gene flow $(N m$ $=2.02)$. The correlation between genetic distance and gene flow was $-0.95(\mathrm{p}=0.06)$ and between geographic distance and gene flow was $-0.78(\mathrm{p}=0.12)$. There was a geographic cline of variability across an East-West axis, influenced as well by the Amazon River, suggesting the river could be a barrier to gene flow. Although threatened, these Rosewood populations retain high diversity, with the highest levels in the Manaus population, which has been protected for over 42 years in a Reserve.
\end{abstract}

KEYWORDS: RAPD, linalool, gene flow, Amazon Rainforest.

\section{Padrão geográfico de diversidade genética em populações naturais de Pau-rosa (Aniba rosaeodora), na Amazônia Central}

\begin{abstract}
RESUMO
O Pau-rosa (Aniba rosaeodora Ducke, Lauraceae) é uma árvore amazônica fonte do mais puro linalol, o qual é o principal componente do seu óleo essencial e muito valioso no mercado internacional de perfumaria. Após várias décadas de intensa exploração, a espécie foi levada à categoria de ameaçada de extinção. Quatro populaçōes naturais distribuídas na bacia Amazônia Central foram avaliadas quanto ao nível e a distribuição da diversidade genética. Trinta e cinco marcadores RAPD reprodutíveis foram gerados, dos quais 32 foram polimórficos $(91,4 \%)$. A diversidade foi maior dentro das populaçôes $(76,5 \%$; $\mathrm{p}<0,0001)$ e a distribuição geográfica contribuiu para a diferenciação entre as populações $(23,4 \% ; \mathrm{p}<0,0001)$. A AMOVA indicou que pode haver uma influência parcial do Rio Amazonas no fluxo gênico $(3,3 \% ; p<0,0001)$, mas foram identificadas evidências de fluxo gênico atravessando o rio. Houve diferenças significativas nas freqüências dos marcadores $(\mathrm{p}<0,05)$ e o fluxo gênico estimado foi relativamente baixo $(N m=2,02)$. A correlação entre a distância genética e o fluxo gênico foi de $-0,95(\mathrm{p}=$ $0,06)$ e para a distância geográfica e o fluxo gênico foi de $-0,78(\mathrm{p}=0,12)$. Houve um padrão geográfico de variabilidade ao longo do eixo Leste - Oeste, influenciado também pelo Rio Amazonas, o que sugere que o rio poderia funcionar como uma barreira para o fluxo gênico. Apesar de ameaçadas, estas populaçóes de Pau-rosa possuem alta diversidade, com o maior valor na população de Manaus, que vem sendo protegida por 42 anos em uma reserva.
\end{abstract}

PALAVRAS-CHAVE: RAPD, linalol, fluxo gênico, floresta úmida amazônica.

\footnotetext{
1 Instituto Nacional de Pesquisas da Amazônia - INPA. Curso de Pós-graduação em Ciências de Florestas Tropicais; Bolsista do Programa Internacional de Pós-graduação da Fundação Ford. baianorural@yahoo.com.br

2 Embrapa Amazônia Ocidental

3 Instituto Nacional de Pesquisas da Amazônia - INPA/CPST

${ }_{4}^{4}$ Embrapa Amazônia Ocidental

${ }^{5}$ Embrapa Amazônia Ocidental

${ }^{6}$ Univercidade Federal do Amazonas - UFAM
} 


\section{INTRODUCTION}

Rosewood (Aniba rosaeodora Ducke, Lauraceae) is an evergreen perennial tree species occurring predominantly in non-flooded areas and can reach 30 meters in height (Ducke, 1938; Kubitzki \& Renner, 1982). It has a wide geographic range, being found across the Amazon basin in the Brazilian states of Acre, Amapá, Amazonas, Pará, Roraima, and in the Amazonian portions of Guyana, Venezuela, Peru and Colombia (Ducke, 1938; SUDAM, 1972). The highest density population is found in the Central Amazon predominantly in the state of Amazonas (Leite et al., 1999; May \& Barata, 2004), usually less than 2 trees/ha (Loureiro et al., 1979).

To date no consistent data is available regarding Rosewood's mating system and reproductive ecology. The species appears to have an allogamous mating system, which is common in other Lauraceae species (Gibson \& Wheelwright, 1995; 1996; Moraes \& Monteiro, 2002). It is insect pollinated, with Meliponinae bees apparently most important (Kubitzki \& Kurz, 1984) and, possibly, small Thysanoptera insects (Spironello et al., 2003; W. R. Spironello, personal communication). Seeds are dispersed by animals, principally by birds, such as Toucans, and secondarily by small rodents (Spironello et al., 2003).

The Brazilian Institute of the Environment and Renewable Natural Resources included Rosewood in the list of threatened species (IBAMA, 1992) because it is considered an overexploited species being driven towards economic extinction. This is due to excessive logging during the past half-century, with the aim of extracting its essential oil from its wood. This essential oil is rich in linalool, a very valuable and expense product. Rosewood essential oil is used in the top products of the perfume industry and has no better natural or artificial substitute (May \& Barata, 2004; Santos et al., 2004). As a result, Rosewood is considered a high priority for collection and in situ conservation in Brazil (Vieira, 1999). Although there is considerable evidence about loss of variability in other threatened species or those that have suffered heavy exploitation (Frankham, 1995; Matocq \& Villablanca, 2001; Avise, 2004; Baucon et al., 2005), for Rosewood no data is available.

An understanding of the amount and distribution of genetic diversity within and between natural populations, and genetic divergence among populations, is important for defining forest management and conservation strategies in order to sustainably use forest resources (Lindenmayer et al., 2000; Finkeldey \& Ziehe, 2004; Baucon et al., 2005). Over the last decade, analyses of genetic diversity and implications for conservation strategies have employed a large range of molecular markers, such as RFLP, AFLP, RAPD and microsatellites (Haig, 1998; Petit et al., 1998; Avise, 2004).
Although somewhat problematic, RAPD markers can be important tools when appropriate care is taken to evaluate marker consistency and to analyze the data with recognition of their limitations (Lynch \& Milligan, 1994; Perez et al., 1998).

This study focused on natural populations of Rosewood in Central Amazonia, especially in eastern Amazonas state, where Rosewood is more abundant. RAPD markers were used: (i) to define the levels of genetic diversity within and between remaining trees sampled in four regions of natural Rosewood occurrence;(ii) to analyze genetic diversity as a function of geographic distribution, and (iii) to contrast diversity indexes estimated for three intensively harvested populations versus a fourth that was protected in a forest reserve for the last 42 years.

\section{MATERIAL AND METHODS}

\section{PLANT MATERIAL}

Fresh leaf tissue was sampled from adult plants in traditional communities close to urban areas in the municipalities of Maués ( $\left.3^{\circ} 22^{\prime} \mathrm{S}, 57^{\circ} 43^{\prime} \mathrm{W}\right)$, Parintins $\left(2^{\circ}\right.$ $\left.37^{\prime} \mathrm{S}, 56^{\circ} 44^{\prime} \mathrm{W}\right)$, Silves ( $\left.2^{\circ} 52^{\prime} \mathrm{S}, 58^{\circ} 12^{\prime} \mathrm{W}\right)$ and Manaus $\left(2^{\circ}\right.$ $\left.37^{\prime} \mathrm{S}, 60^{\circ} 11^{\prime} \mathrm{W}\right)$, Amazonas state, Brazil. The distance from one population to another (plants from each municipality were considered as a population) varies from 87 to $370 \mathrm{~km}$ (Figure 1). Rosewood occurs at low density in natural forest (less than 2 trees/ha, Loureiro et al., 1979) and is found in many parts of the Amazon Basin; RADAMBRASIL identified 25 points across the basin even though it was not a priority species and may be unreliable (Sylvain Desmoulière, INPA, personal communication, 2008). Our four localities have reasonable information on adult tree occurrence and conservation status based on research and surveys by INPA, UFRA, EMBRAPA and personal observations (Leite et al., 1999; Ohashi, 1999), especially because Rosewood distillation is concentrated today in Maués, Parintins and Manaus (May \& Barata, 2004). In Silves there is no distillery but Rosewood is concentrated in an area $10 \mathrm{~km}$ from urban center, which has been declared a Forest Reserve by Associação Vida Verde (AVIVE). Only in Manaus, at Adolphe Ducke Forest Reserve, we can find survey of adult tree density (between 3 and 4 adult trees per hectare; Alencar \& Fernandes, 1978).

When dominant markers are used sample sizes should be as large as possible (Lynch \& Milligan, 1994; Nei, 1987), but it is hard to find Rosewood in the natural forest available. In the Adolpho Ducke Forest Reserve, Manaus, Rosewood has been extensively surveyed ( $3-4$ tree/ha as found by Alencar \& Fernandes, 1978), since have been protected for the last 42 years permitting larger sample sizes. In this case, 37 trees were sampled, but only 24 trees from each of the other populations 


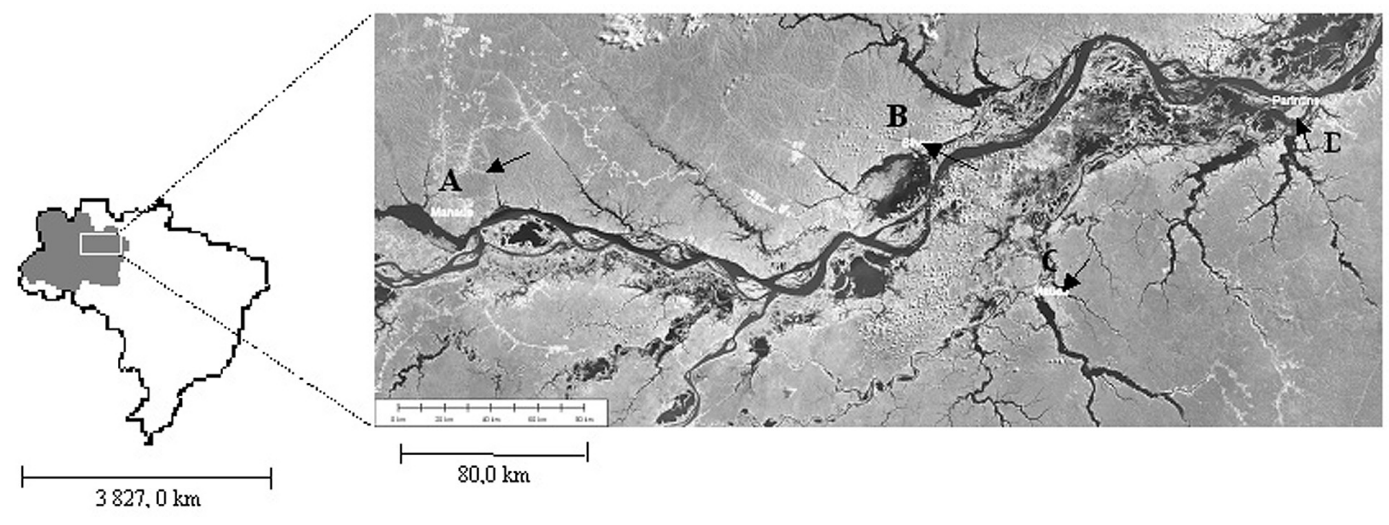

Figure 1 - Geographic location of the cities that were used as reference to sample Rosewood trees in the Amazon River Basin, Amazonas state, Brazil: A Manaus (Adolpho Ducke Forest Reserve); B - Silves; C - Maués; e D - Parintins. Source: GISLAB - INPA (Landsat TM).

- with difficulty. Leaves were conditioned in plastic flasks with silica gel and stored at $-20{ }^{\circ} \mathrm{C}$ in the Plant Biotechnology Laboratory, Embrapa Amazônia Ocidental, Manaus.

\section{DNA EXTRACTION, RAPD REACTIONS AND BAND VISUALIZATION}

The DNA was extracted from young leaf tissue following Edwards et al. (1991) and quantified by spectrophotometry (GeneQuant pro RNA/DNA Calculator). The PCR reactions included $30 \mathrm{ng}$ of DNA, $2.50 \mathrm{U}$ of Taq DNA polymerase, $3.0 \mathrm{mM}$ of $\mathrm{MgCl}_{2}, 500 \mathrm{nM}$ of primer, $100 \mu \mathrm{M}$ of each dNTP and $0.1 \%$ BSA for a final volume of $25 \mu \mathrm{L}$, and were optimized for Rosewood by Santos et al. (2007). PCR was carried out in a Perkin Elmer Gene Amp PCR System 2400 thermal cycler, programmed for one cycle of 1 minute at $90^{\circ} \mathrm{C}$ followed by 35 cycles of $1 \mathrm{~min}$ at $92^{\circ} \mathrm{C}, 2 \mathrm{~min}$ at $30^{\circ} \mathrm{C}$ and 1 minute at $72^{\circ} \mathrm{C}$, with an annealing temperature of $35^{\circ} \mathrm{C}$ and a final cycle of $5 \mathrm{~min}$ at $72^{\circ} \mathrm{C}$ and $4^{\circ} \mathrm{C}$ until processing. Twenty-one primers were screened and four were used (5'-AAGTCCGCTC-3'; 5'-AAGACCCCTG-3'; 5'-GGCACGCGTT-3' and 3'-AATCGGGCTG-5'). Electrophoresis was run for 3 hours in TBE $1 \mathrm{X}$ buffer, 1.5 $\%$ agarose gels stained with ethidium bromide $(0.5 \mathrm{mg} / \mathrm{ml})$ limited to $5 \mathrm{~V} / \mathrm{cm}$. RAPD patterns were visualized under UV light and captured with a Kodak Digital Zoom Camera photo-documentation system and accessory software (Kodak Digital Science DC120 Kit Gel Documentation Accessory Kit and 1D Image Analysis Software). Only reliable markers with reproducibility index above $80 \%$ were included in the analysis (Santos et al., 2007).

\section{GENETIC AND STATISTIC ANALYSIS}

In order to minimize the recognized limitations of the RAPD methodology, especially with respect to transforming gel fragment frequencies into allele frequencies, we assumed each locus can be treated as a two-allele system, with only one of the alleles per locus being amplifiable by the PCR. Hence, these frequencies were calculated considering the correction for dominance and that RAPD fragments from different loci do not comigrate to the same place on a gel (Lynch \& Milligan, 1994). Also, due to this limitation of RAPD markers, all parameters analyzed (e.g., gene flow, variability and genetic distance) will consider that RAPD fragments are simply DNA loci. The geographic distances were estimated using maps and scaled images from Landsat TM available at the GISLAB (Laboratory of Geographic Information Systems at the National Institute for Amazonian Research, INPA). The percentage of polymorphism for each population and the estimates of gene flow were obtained following Slatkin \& Barton (1989) using POPGENE 1.32 (Yeh et al., 1999). Fisher's Exact test (Raymond \& Rousset, 1995) was used to detect disequilibria in the band frequencies among populations, using TFPGA software (Miller, 1997) and selecting the corrections options for RAPD bands (Lynch \& Milligan 1994). The distribution of genetic diversity within and among populations was tested by Analysis of Molecular Variance (AMOVA) using Arlequim 2.0 (Schneider et al., 2000), which is appropriate for RAPD diversity analyses (Excoffier et al., 1992; Huff et al., 1993; Stewart \& Excoffier, 1996; Lacerda et al., 2001). Nei's diversity index (Nei, 1973) was calculated in POPGENE, and correlated to the number of trees (Pearson's correlation, $\mathrm{p}<0.005$ ) in order to verify any bias caused by number of trees sampled from different populations (37 in Manaus and 24 in the other populations).

We used AMOVA to estimate the river's affect on gene flow. Two groups of populations separed by Amazon river were compared: the southern group, composed of the Maués and Parintins populations, and the northern group, composed of the Manaus and Silves populations (see Figure 1). The significance level for the variance components was calculated by conducting 1000 permutations. Nei's genetic distance (Nei, 1978) between populations was calculated and an UPGMA dendrogram was generated using TFPGA. The similarity 
matrix obtained from NTSYS - v. 1.60 (Rohlf, 1990) was used as the basis for Principal Components Analysis (PCA) of the spatial distribution of genetic diversity. In order to enhance the PCA figure and to facilitate the discrimination of all samples from each population, we used Word's draw tools to add population specific symbols. Matrix correlations for geographic distance, genetic distance (Nei, 1978) and gene flow were calculated by Mantel's test (Mantel, 1967), using TFPGA with 1000 permutations.

\section{RESULTS}

A total of 51 RAPD markers were scored, of which 35 were used cause they presented better reproducibility, above 80\% (Santos et al., 2007). Thirty-two of these bands were polymorphic (91.4\%). The amplified fragments ranged from 450 to $2000 \mathrm{bp}$.

The percentage of polymorphism was as follows: Manaus 83.0\%; Silves 76.5\%; Maués 79.2\%; and Parintins 75.0\%. The Analysis of Molecular Variance (AMOVA; Table 1) showed that $76.6 \%$ of the genetic diversity was found within populations and $23.4 \%$ among populations ( $\mathrm{p}<0.001)$, and these estimates were not biased by the number of trees sampled (Figure 2). When the populations from the north (Manaus and Silves) and from the south (Maués and Parintins) of the Amazon River were grouped and compared, differences among populations were lower $(21.0 \%)$, as was the diversity within populations (75.7\%). Differences between the southern and the northern group explained the rest of the variation $(3.3 \%$; $\mathrm{p}<0.001$; Table 1).

Fisher's exact test indicated the existence of disequilibria for marker frequencies in all the comparisons among populations ( $\mathrm{p}<0.05)$. One marker $(650 \mathrm{~kb}$; primer 3'AATCGGGCTG-5') occurred exclusively in plants from Maués and Parintins (Figure 3), and another only in plants from Manaus (figure not shown).

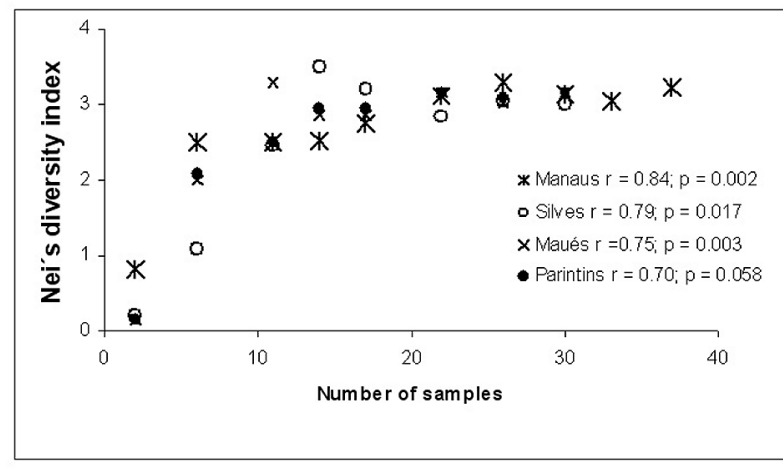

Figure 2 - Number of sampled trees plotted against the Nei's (1973) diversity index (x 10) for each Rosewood (Aniba rosaeodora Ducke) population sampled in Amazonas state Brazil.
The three Rosewood populations from the lower Amazon River (Silves, Maués and Parintins) clustered together and diverged from Manaus (Figure 4), in close agreement with their geographic distance and gene flows (Table 2). The Principal Components Analysis (Figure 5) illustrated appropriately the same relationships, with the advantage of allowing the observation of the dispersion of individual trees within and among populations. In addition, the overlapping of populations in the southern group (Maués e Parintins) is clearer in this two-dimensional representation. Two trees of the Silves populations clustered with Maués and Parintins, illustrating some South to North gene flow.

Mantel's test showed a moderate and positive correlation between the matrices of genetic (Nei, 1978) and geographic distance $(\mathrm{r}=0.74 ; \mathrm{p}=0.19)$, and a negative correlation between the geographic distance and gene flow $(\mathrm{Nm})(\mathrm{r}=-$ $0.78 ; \mathrm{p}=0.12)$. As expected, a high and negative value was found $(\mathrm{r}=-0.95 ; \mathrm{p}=0.06)$ between genetic distance and gene flow (Table 2).

\section{DISCUSSION}

The sample size in any population genetic study should be as large as possible for reliable statistical analysis. However, it is not easy to find Rosewood trees in the forest, as they are rare, especially after harvesting. There is no significant relationship between sample size and variability in these Rosewood populations (Figure 2), suggesting that 109 trees from four populations is sufficient sample. Sampling error can be reduced further by using a large and reliable set of loci (Nei, 1987). Considering the procedures used to evaluate marker consistency and reproducibility (Lynch \& Milligan, 1994; Perez et al., 1998; Santos et al., 2007), the 32 RAPD loci are sufficient for the current study.

\section{DISTRIBUTION OF THE GENETIC DIVERSITY IN ROSEWOOD POPULATIONS}

Similar to most tropical tree species with outcrossing mating systems (Bawa, 1992), within population genetic diversity is greater in Rosewood than among population

Table 1 - AMOVA showing the distribution of diversity within and among four populations and two groups of populations for Rosewood (Aniba rosaeodora).

\begin{tabular}{lll}
\hline Source of variation & $\%$ variation & $\mathrm{p}^{*}$ \\
\hline Between populations & 23.4 & $<00001$ \\
Within populations & 76.6 & $<00001$ \\
Total & 100.0 & - \\
\hline Between groups & 3.3 & $<00001$ \\
Between populations within groups & 21.0 & $<00001$ \\
Within populations & 75.7 & $<00001$ \\
\hline \multicolumn{1}{l}{ Total } & 100.0 & - \\
\hline
\end{tabular}

Note: *Significance of the tests 


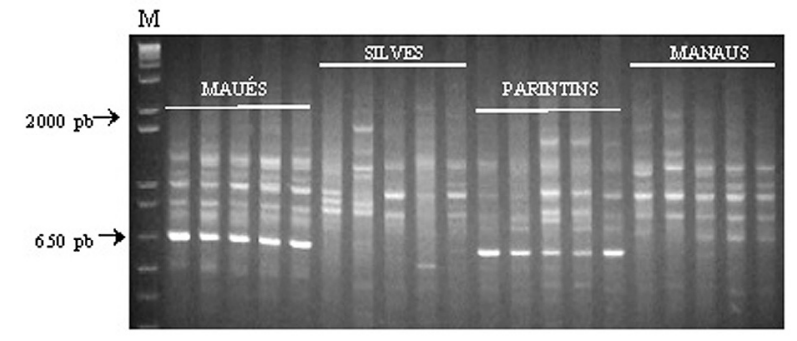

Figure 3 - RAPD patterns generated with primer (3'-AATCGGGCTG-5') in four locations of Amazonas state, Brazil. The $650 \mathrm{pb}$ fragment was found exclusively in trees from Maués and Parintins, both located south of the Amazon River. $\mathrm{M}=1 \mathrm{~kb}$ Ladder (Gibco).

Table 2 - Matrix of geographic distance (GD in km) and gene flow (Nm) among populations of Rosewood (Aniba rosaeodora).

\begin{tabular}{lcccccc}
\hline & \multicolumn{2}{c}{ Manaus } & \multicolumn{2}{c}{ Silves } & \multicolumn{2}{c}{ Maués } \\
\cline { 2 - 7 } & GD & $\mathrm{Nm}$ & $\mathrm{GD}$ & $\mathrm{Nm}$ & $\mathrm{GD}$ & $\mathrm{Nm}$ \\
\hline Silves & 200 & 2.5 & & & & \\
Maués & 264 & 2.7 & 87 & 3.3 & & \\
Parintins & 370 & 2.4 & 170 & 3.9 & 135 & 4.4 \\
\hline
\end{tabular}

diversity. This pattern has been reported also in previous studies using RAPDs in tropical tree species (Cardoso et al., 1998; Pither et al., 2003).

High variability in the tropical species of the Lauraceae family has been associated with its dioeciousness, protogyny, insect pollination and animal-mediated seed dispersal (Gibson \& Wheelwright, 1995; 1996; Moraes \& Monteiro, 2002), although low RAPD variability was recently reported in an endangered woody non-tropical Lauraceae species (ZhongSheng et al., 2005).

Similar to the situation in most Amazonian tree species, few studies have focused on Rosewood's reproductive biology (Kubitzki \& Kurtz, 1984; Spironello et al., 2004) and there is still no consensus on its mating system. Hence, it is difficult to clearly explain the high variability found in this study. Nonetheless, Rosewood's variability is similar to that of other Lauraceae tree species, so the high variability was not unexpected.

Nevertheless, low genetic diversity is likely in threatened species or those that suffered intense and predatory exploitation historically (Frankham 1995; Matocq \& Villablanca, 2001; Baucon et al., 2005). Paradoxically, in tropical species that have suffered intense exploitation [as well as non-tropical ones reviewed by Avise (2004)], recent studies using molecular tools have shown high diversity values, e.g., Dinizia excelsa (Fabaceae; Dick et al., 2003) and Mahogany (Swietenia macrophylla King, Meliaceae; Lemes et al., 2003). The harvester's preference for individuals with

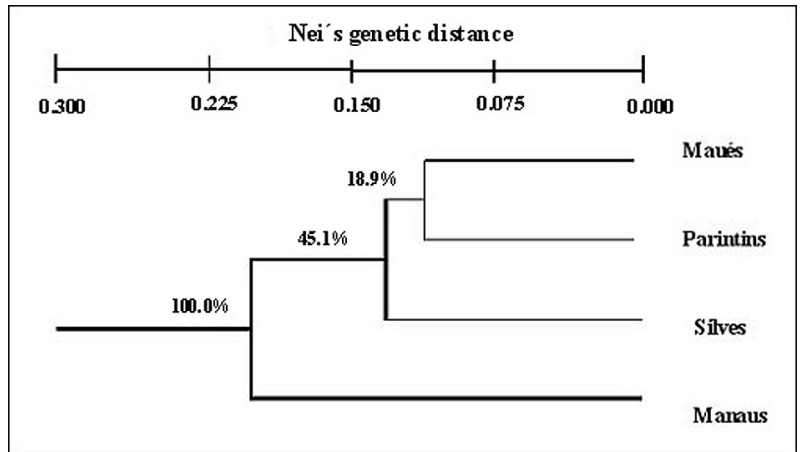

Figure 4 - Dendrogram based on Nei's (1978) genetic distance and UPGMA of four Rosewood (Aniba rosaeodora Ducke) populations. The values over the nodes represent the percentage of loci that supported the analysis.

greater diameter at breast height results in the removal of only a part of a population's diversity, and the rest remains in the earlier stages (seedlings and juveniles). In fact, Santos (2004) demonstrated a slight but significantly higher polymorphism in seedlings of Rosewood in comparison to the adult stage in the Adolpho Ducke Forest Reserve (Manaus population), supporting such a hypothesis (but see Sezen et al., 2005). Moreover, high outcrossing rates (expected in Rosewood) and large effective population sizes have been invoked as factors that would maintain the genetic diversity and structure of the population even under silvicultural management (RobledoAnuncio et al., 2004).

We identified the highest polymorphism (83\%) in the Manaus population and it is also more dispersed in the PCA (Figure 5). This variability may result from the long-term protection of the Reserve, and further detailed comparison of molecular diversity should be undertaken in harvested and non-harvested areas to confirm this hypothesis. On the other hand, in Parintins, the least diverse population, genetic

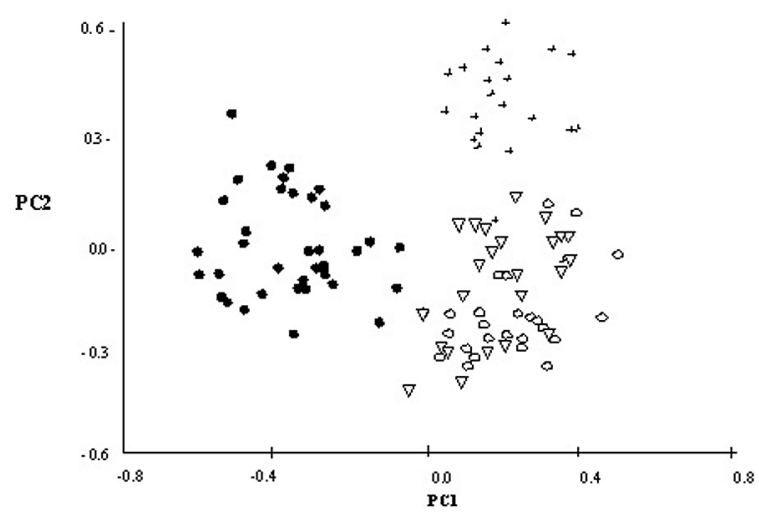

Figure 5 - Principal Component Analysis based on genetic similarity among individuals in four Rosewood (Aniba rosaeodora Ducke) populations: Manaus (Adolpho Ducke Forest Reserve) $(\bullet)$; Silves $(+)$; Maués $(\sigma)$; and Parintins $(\Delta)$. The PC1 axis explained $25.6 \%$ and PC2 axis explained $10.1 \%$ of the total genetic diversity. 
erosion may have occurred as a result of over-exploitation. However, these hypotheses require further study, since there is no statistical evidence of differences among these populations' diversity.

\section{DIFFERENTIATION AND GEOGRAPHIC DISTRIBUTION PATTERN}

The high divergence among populations detected by AMOVA corroborates Figures 5 and 4, and shows a clear geographic patterning of Rosewood populations. Note that the Maués and Parintins populations are located on the same side of the Amazon River (Figure 1), and grouped together in the dendrogram (Figure 4) as well as being mixed together in the PCA (Figure 5). This pattern suggests high gene flow between these populations, also supported by sharing a unique RAPD band (Figure 3). High rates of seed and pollen movement across long distances are common in tropical tree populations (Campbell \& Peart, 2001; Burczyk et al., 2004). In fact, Rosewood's reproductive ecology tends towards high seed movement (Spironello et al., 2003; Spironello et al., 2004).

The gene flow estimated among the Manaus population and the others has a similar level of magnitude, certainly because the Manaus population is slightly less genetically distant from the population in Silves than it is from the populations in the southern group (Maués and Parintins, Table 2). This partially explains the divergence observed in the dendrogram and the PCA, since increasing geographic distance implies decreased gene flow and increased genetic distance (Gregorius, 1987; Bossart \& Prowell, 1998). In fact, Mantel's test result shows a moderate correlation $(r=0.74 ; p$ $=0.19$ ) between geographic and genetic distance, supporting the hypothesis of isolation by distance, as reported in other tropical tree studies using both RAPD and co-dominant molecular markers (Collevatti et al., 2001; Degen et al., 2001).

Note that Maués is geographically closer to Silves than it is to Parintins (GD in Table 2), but the estimate for the gene flow between Maués and Parintins was higher than it was between Maués and Silves. The observed divergence between the populations of Maués and Silves could be explained by the existence of a barrier to gene flow. We suggest that this barrier is the Amazon River. Initial results on seed movement in Rosewood showed that Toucans are very effective removing agents (Spironello et al., 2003; Spironello et al., 2004), but so far no concise information about both their flight capacity in tropical forest conditions and seed dispersal are available, and we do not know whether these birds could cross the Amazon River as easily as they move among trees in the forest canopy.

On the other hand, note that two Silves trees group with the Maués-Parintins cluster, suggesting South to North seed dispersal (Figure 5). As reported in other studies of tropical tree species, gene flow can occur among adult trees separated by hundreds of kilometers or by forest fragmentation (Dick et al., 2003; Burczyk et al., 2004). Hence, all these apparent correlations between genetic and seed and fruit ecology in Rosewood are good clues but are not conclusive.

\section{RECOMMENDATIONS FOR CONSERVATION PLANNING}

Leite et al. (1999) recommended further studies on diversity and ecology in the Rosewood population of the Adolpho Ducke Forest Reserve, given its known history and protected status. Since that Reserve's populations seem to be maintaining their natural diversity, we suggest that that Reserve's features should be taken into account when planning new reserves.

Given the amount and patterning of diversity among the populations studied here, we suggest that: (1) sampling for breeding or conservation should include as many localities as possible in order to capture a good number of rare alleles, which are normally found by sampling more populations (Brown \& Marshall, 1995); (2) as many of these areas as possible need to be conserved to guarantee future maintenance of genetic diversity; (3) both harvested and non-harvested populations in other areas of the Amazon forest should be studied with more accurate molecular tools, such as microsatellite markers; and (4) to better understand gene flow among proximate and distant populations, ecological studies on seed dispersal distances and seed removal in natural sites, integrated with molecular studies and mating system analysis, are necessary to enhance knowledge of Rosewood population biology.

\section{LITERATURE CITED}

Alencar, J.; Fernandes, N.P. 1978. Desenvolvimento de árvores nativas em ensaios de espécies. 1. Pau - rosa (Aniba duckei Kostermans). Acta Amazônica, 8 (4): 523 - 541.

Avise, J.C. 2004. Molecular markers, natural history, and evolution. Sinauer Associates, Inc. Publishers, $2^{\text {nd }}$, Sunderland, MA. $541 \mathrm{pp}$.

Baucon, R.S.; Estill, J.C.;Cruzan, M.B. 2005. The effect of deforestation on the genetic diversity and structure in Acer saccharum (Marsh): Evidence for the loss and restructuring of genetic variation in a natural system. Conserv. Genetics, 6: 39-50.

Bawa, K.S. 1992. Mating system, genetic differentiation, speciation in tropical rain forest plants. Biotropica, 24: 250-255.

Bossart, J.L.; Prowell, D.P. 1998. Genetic estimates of population structure and gene flow: limitations, lessons, and new directions. Trends Ecol. Evol., 13: 202-206.

Brown, A.H.D.; Marshall, D.R. 1995. A basic sampling strategy: theory and practice. In: Guarino, L.; Rao, V.R.; Reid, R. (Eds). Collecting plant genetic diversity - Technical guidelines. CAB International, Wallingford, Australia. p. 75-91. 
Burczyk, J.; Difazio, S.P.; Adams, W.T. 2004. Gene flow in forest trees: how far do genes really travel? For. Genetics, 11: 1-14.

Campbell, O.W.; Peart. D.R. 2001. High seed dispersal rates in faunally intact tropical rain forest: theoretical and conservation implications. Ecological Letters, 4: 491-499.

Cardoso, M.A.; Provan, J.; Powell, W.; Ferreira, P.C.G.; Oliveira, D.E. 1998. High genetic differentiation among remnant populations of the endangered Caesalpinia echinata Lam (Leguminosae Caesalpinioideae). Mol. Ecol., 7: 601-608.

Collevatti, R.G.; Grattapaglia, D.; Hay, J.D. 2001. Population genetic structure of the endangered tropical tree species Caryocar brasiliense, based on variability at microsatellite loci. Mol. Ecol., 10: 349-356.

Degen, B.; Henri, C.; Bandou, E.; Maggia, L.; Chevallier, M.H.; Leveau, A.; Kremer, A. 2001. Fine-scale spatial genetic structure of eight tropical tree species as analyzed by RAPDs. Heredity, 87(4): 497- 507.

Dick, C.W.; Etchelecu, G.; Austerlitz, F. 2003. Pollen dispersal of tropical trees (Dinizia excelsa: Fabaceae) by native insects and African honeybees in pristine and fragmented Amazonian rainforest. Mol. Ecol., 12: 753-764.

Ducke, A. 1938. Lauráceas aromáticas da Amazônia brasileira. In: Anais da Reuniāo Sul-Americana de Botânica, Jardim Botânico Ed., Rio de Janeiro. p. 55-65.

Edwards, K.; Johnstone, C.; Thompsons, C. 1991. A simple and rapid method for the preparation of plant genomic DNA for PCR analysis. Nucleid Acids Res., 19(6): 1349.

Excoffier, L.; Smouse, P.E.; Quattro, J.M. 1992. Analysis of molecular variance inferred from metric distance among DNA haplotypes: application to human mitocondrial restriction data. Genetics, 131: 479-491.

Finkeldey, R.; Ziehe, M. 2004. Genetic implications of silvicultural regimes. For. Ecol. Manage., 197: 231-244.

Frankham, R. 1995. Conservation genetics. Annu. Rev. Genet., 29: 305-327.

Gibson, J.P; Wheelwright, N.T. 1995. Genetic structure in a population of tropical tree Ocotea tenera (Lauraceae): influence of avian seed dispersal. Oecologia, 10: 49.54.

Gibson, J.P.; Wheelwright, N.T. 1996. Mating system dynamics of Ocotea tenera (Lauraceae) a gynodioecious tropical tree. Amer. J. Bot., 83: 890-894.

Gregorius, H.R. 1987. The relationship between the concepts of genetic diversity and differentiation. Theor. Appl. Genet., 74: 397-401.

Haig, S.M. 1998. Molecular contributions for conservation. Evolution, 79: 413-425.

Huff, D. R.; Peakall, R.; Smouse, P. E. 1993. RAPD variation within and among natural populations of outcrossing buffalograss [Buchloë dactyloides (Nutt.) Engelm.]. Theor. Appl. Genet., 86: 927-934.

IBAMA. 1992. Portaria $N^{\circ}$ 37. Diário Oficial da União de 3 de abril de 1992. Brazilia, DF.
Kubitzki, K.; Renner, S. 1982. Lauraceae I (Aniba and Aiouea). Flora Neotropica 31. New York, New York Botanical Garden 125pp.

Kubitzki, K.; Kurz, H. 1984. Sincronized dichogamy and dioecy in Neotropical Lauraceae. Plant Syst. Evol., 147: 253-266.

Lacerda, D. R.; Acedo, M. D. P.; Lemos Filho, J. P.; Lovato, M. B. 2001. Genetic diversity and structure of natural populations of Plathymenia reticulata (Mimosoideae), a tropical tree from the Brazilian Cerrado. Mol. Ecol., 10: 1143-1152.

Leite, A.M.C.; Sampaio, P.T.B.; Barbosa, A.P.; Quisen, R.C. 1999. Diretrizes para o resgate e conservação da variabilidade genética de espécies Amazônicas I - Pau-rosa. Documento 6, Embrapa Amazônia Ocidental, Manaus, Brazil. 43pp.

Lemes, M.; Gribel, R.; Proctor, J.; Grattapaglia, D. 2003. Population genetic structure of mahogany (Swietenia macrophylla King Meliaceae) across the Brazilian Amazon based on variation at microsatellite loci: implications for conservation. Mol. Ecol., 12: 2875-2883.

Lindenmayer, D.B.; Margules, C.R.; Botkin, D.B. 2000. Indicators of biodiversity for ecologically sustainable forest management. Conserv. Biol., 14: 941-950.

Loureiro, A. A.; Silva, M. F.; Alencar, J. C. 1979. Essências madeireiras da Amazônia. Vol. 2. INPA-SUFRAMA, Manaus, AM. 245p.

Lynch, M.; Milligan, B.G. 1994. Analysis of population genetic structure with RAPDS markers. Mol. Ecol., 3: 91-99.

Mantel, N. 1967. The detection of disease clustering and generalized regression approach. Cancer Res., 27: 209-220.

Matocq, M.D.; Villablanca, F.X. 2001. Low genetic diversity in an endangered species: recent or historic pattern? Biol. Conserv., 98: 61-68.

May, P.H.; Barata, L.E.S. 2004. Rosewood exploitation in the Brazilian Amazon: options for sustainable production. Econ. Bot., 58: 257-265.

Miller, M.P. 1997. Tools for Population Genetic Analysis (TFPGA). version 13. Northern Arizona University, Flagstaff Arizona.

Moraes, P.L.R.; Monteiro, R. 2002. Taxas de cruzamento em uma população natural de Cryptocarya moschata Nees (Lauraceae). Biota Neotropica, 2 (2) (www.biotaneotropicaorgbr/v2n2/pt/ab stract?article+BN01102022002). acesso: 12/07/2005.

Nei, M. 1973. Analysis of gene diversity in subdivided populations. Proc. Natl. Acad. Sci., 70: 3321-3323.

Nei, M. 1978. Estimation of average heterozygosity and genetic distance from a small number of individuals. Genetics, 89: 583-590.

Nei, M. 1987. Molecular Evolutionary Genetics. Columbia University Press, New York. 512pp.

Ohashi, S. T. 1999. Map presented at $I^{a}$. reunião temática sobre a conservação e utilização de populacões naturais de pau-rosa (Aniba rosaeodora) no Estado de Amazonas. EMBRAPA-CPAA, ManausAM, Brazil. June.

Perez, J.; Albornoz, T.; Dominguez, A. 1998. An evaluation of RAPD fragment reproducibility and nature. Mol. Ecol., 7: 1347-1357. 
Petit, R.J.; EL-Mousadik, A.; Pons, O. 1998. Identifying populations for conservation on the basis of molecular markers. Conserv. Biol., 12: 844-855.

Pither, R.; Shore, J.S.; Kellman, M. 2003. Genetic diversity of the tropical tree Terminalia amazonia (Combretaceae) in naturally fragmented populations. Heredity, 91, 307-313.

Raymond, M.; Rousset, F. 1995. An exact test for population differentiation. Evolution, 49: 1280-1283.

Robledo-Anuncio, J.J.; Smouse, P.E.; Gil, L.; Alia, R. 2004. Pollen movement under alternative silvicultural practices in native populations of Scots pine (Pinus sylvestris L.) in central Spain. For. Ecol. Manage., 197: 245-255.

Rohlf, F.J. 1990. NTSYS- PC: Numerical Taxonomy and Multivariate Analysis System. Version 16. Applied Biostatistics, Setauket, New York.

Santos, A.S.; Antunes, A.M.S.; D’Avila, L.A. 2004. New natural Linalol sources: research and industrial application. Perf. Flav., 29: 38-43.

Santos, R.P. 2004. Avaliação da diversidade genética de populaçôes naturais de Pau - rosa (Aniba rosaeodora, Ducke) por meio de marcadores moleculares RAPD. Dissertação de Mestrado. INPA/ UFAM. Manaus, AM. $81 \mathrm{pp}$.

Santos, R.P.; Angelo, P.C.S; Sampaio, P.T.B; Cruz, J.S. 2007. RAPD em Pau-Rosa (Aniba rosaeodora Ducke): adaptação do método para coleta e amostra in situ, ajustes nas condições de PCR e apresentação de processo para selecionar bandas representativas. Acta Amazônica, 37(2): 253-259

Schneider, S.; Roessli, D.; Excoffier, L. 2000. Arlequim version 2.0: A software for population genetic data analysis. Genetics and Biometry Laboratory, University of Geneva, Switzerland.

Sezen, U.U.; Chazdon, R.; Holsinger, K.E. 2005. Genetic consequences of tropical second-growth forest regeneration. Science, 307: 891.

Slatkin, M.; Barton, N.H. 1989. A comparison of three indirect methods for estimating average gene flow. Evolution, 43: 1346-1349.
Spironello, W. R.; Sampaio, P.T.B.; Vieira, G.; Barbosa, A.B. 2003. Ecologia reprodutiva do pau-rosa (Aniba rosaeodora Ducke, Lauraceae) em uma mata de terra firme na Amazônia Central. In: Higuchi, N.; Santos, J.A.; Sampaio P.T.B.; Marenco, R.; Ferraz, J.; Sales; P.C.; Saito, M.; Matsumoto, S. (Eds). Projeto JacarandaFase II: Pesquisas Florestais na Amazônia Central. Manaus: INPA, Manaus, AM. p. 69-87.

Spironello, W.R.; Sampaio, P.T.B.; Ronchi-Teles, B. 2004. Produção e predação de frutos em Aniba rosaeodora Ducke var amazônica Ducke (Lauraceae) em sistema de plantio sob floresta de terra firme na Amazônia Central. Acta bot. Brás., 18: 801 - 807.

Stewart, C. N.; Excoffier, L. 1996. Assessing population genetic structure and variability with RAPD data: application to Vaccinium macrocarpon (American Cranberry). J.Evol. Biol., 9: 153-171.

SUDAM. 1972. Extrativismo do Pau-rosa (Aniba duckei Koster., Aniba rosaeodora Ducke). Aspectos sócio-econômicos: a silvicultura da espécie. Documentos da Amazônia 3, (1/4):5-55.

Vieira, R.F. 1999. Conservation of medicinal and aromatic plants in Brazil. In: Janick, J. (Ed). Perspectives on new crops and new uses. ASHS Press, Alexandria, VA. p. 152-159 (www.hort. purdue.edu/newcrop/proceedings1999/v4-152.html). acesso: $15 / 11 / 2005$.

Yeh, F.C. Yang, R.C. e Boyle, T. 1999. POPGENE: Microsoft Windowbased freeware for population genetic analysis: version 13: Manual University of Alberta, Edmonton.

Zhong-Sheng, W.; Shu-Qing, A.; Hong, L.; Xin, L.; Jian-Wei, Z.; Yu-Hong, L. 2005. Genetic structure of the endangered plant Neolitsea sericea (Lauraceae) from the Zhoushan Archipelago using RAPD markers. Annals of Botany, 95: 305-313.

Recebido em 10/07/2007

Aceito em 07/03/2008 